\title{
Niğde İli Efendibey Kentsel Dönüşüm Projesi’nin Peyzaj Mimarlığı Açısından İrdelenmesi
}

\author{
Filiz Çetinkaya KARAFAKI 1
}

\begin{abstract}
Özet
Tüm dünyada olduğu gibi ülkemizde de artan nüfus beraberinde artan konut ihtiyacını getirmiștir. Bilinçsiz gelişen konut alanları yanlıș arazi kullanımlarına, betonlaşmaya, ekolojik, ekonomik ve kültürel bozulmalara neden olmaktadır. Kentsel büyümenin kentte sorunlu alanların oluşmasına neden olmasının önüne geçilmesi ve işlevini kaybetmiş çöküntü alanlarının yeniden kente kazandırılması için 13.07.2005 tarih ve 25874 sayılı Belediye Kanunu'nun 73. Maddesi uyarınca kentsel dönüşüm ve gelişim alanı projeleri uygulanabilir. Bu amaçla Türkiye'de birçok çöküntü alanı yenilenmiş, yaşam standartları ve görsel kaliteleri yükseltilmiştir. Niğde Belediyesi sınırları içerisinde bulunan Efendibey Mahallesi Niğde'nin merkez ilçesine yakın bir noktada aldığı göçlerle birlikte yaşanan çarpık kentleşme ile kentin çöküntü alanlarından birisi haline gelmiştir. Efendibey Mahallesi 2012 yılında kentsel dönüşüm kapsamına alınmış ve 121 hektarlık bir alanda 240.000 m2'lik kısmı rekreasyon alanı olacak șekilde projelendirilmiştir. Bu çalışmanın amacı Niğde kenti için bir ilk niteliği taşıyan projenin peyzaj tasarım ve planlama ilkeleri açısından irdelenmesi ve gelecek projeler için kaynak rehber olmasının sağlanmasıdır. Çalışma kapsamında dönüşüm alanı kentsel dönüşüm çalışmalarının amaçları doğrultusunda irdelenmiştir. Sonuçta dönüşüme uğrayan alanın bölge halkının daha sağlıklı bir çevrede yaşamasına olanak sağlayacağı ve Niğde kent kimliği açısından oldukça olumlu gelişmeler sağlayacağı kanısına varılmıştır.
\end{abstract}

Anahtar Kelimeler: Niğde, Niğde Peyzajı, Kentsel Dönüşüm Projesi, Niğde Efendibey Kentsel Dönüşüm Projesi

\section{Scrutinization of Niğde Efendibey Urban Transformatıon Project in Terms of Landscape Architecture}

\begin{abstract}
Population increasing in our country as all over the world brought housing need. Unconscious developing residential areas cause to the wrong land use, concretion, and ecological, economic and cultural distortions. In order to prevent the formation of problematic areas in the city's urban growth and to gain again the distorted areas, urban renewal and development area projects can be applied according to the Article 73 of Municipal Law dated as 13.07.2005 with the number of 25874. For this purpose, many distorted places renovated in Turkey and living standards and visual quality were raised. Efendibey Quarter located in the municipality of Niğde has become one of the city's debris fields of urban sprawl along with the migrations. Efendibey Quarter was included in the urban renewal in 2012 and it was projected to be a recreation area with its 240,000
\end{abstract}

\footnotetext{
${ }^{1}$ Dr. Öğr. Üyesi, Seyahat, Turizm ve Eğlence Hizmetleri Bölümü, Ankara Üniversitesi, Ankara İlgili yazar / Corresponding author: filizcetinkaya@gmail.com
}

Bu makaleye atıf yapmak için- To cite this article Ç. Karafakı, F. (2018). Niğde İli Efendibey Kentsel Dönüşüm Projesi'nin Peyzaj Mimarlı̆̆ı Açısından İrdelenmesi. Afet ve Risk Dergisi, 1(2), 93-105. 
Niğde İli Efendibey Kentsel Dönüșüm Projesi’nin Peyzaj Mimarlığı Açısından İrdelenmesi $\mathrm{m} 2$ of 121 hectares area. The aim of this study is to examine project in terms of landscape design and planning principles which is the first for Niğde and to ensure resource guides for future projects. In the scope of the study, the transformation area was examined in terms of the aims of the urban transformation studies. As a result, it has been reached that the converted area will enable the people of the region to live in a healthier environment and Niğde will provide quite positive developments in terms of the identity of the city. I would like to express my gratitude to Niğde Municipality and Republic of Turkey Prime Ministry Housing Development Administration for their support of this area with their photographs and projects.

Keywords: Niğde, Landscape of Niğde, Urban Transformation Project, Niğde Efendibey Urban Transformation Project

\section{GíRiş}

Kentler karmaşık ve dinamik yapıları olan yerleşim birimleridir. Bu dinamik yapıları nedeniyle de kuruldukları günden bu yana sürekli değişim içinde olmuşlardır (Karadağ ve Miroğlu, 2012). Modern ve konforlu hayatın simgesi haline getirilen kentlerin zamanla göç baskısı ile başa çıkamaması sonucu gecekondulaşma başta olmak üzere birçok sorun ile yüz yüze gelmesi kaçınılmaz olmuştur.

Gelişmiş ülkeler hızla artan nüfus baskısının ve çarpık kentleşmenin önüne geçebilmek için bilimsel temellere ve multidisipliner çalışmalara dayalı, alan kullanıcısını, alan yönetimini ve ekolojik verileri bir araya toplayan kentsel dönüşüm projeleri geliştirmektedirler.

Kentsel dönüşüm yaklaşımı dönüşümün sadece yıkıp yeniden yapmak olarak algılanmadığı, iyileștirme, yapılandırma, canlandırma gibi farklı yolların uygulandığı, bölgede yaşayan toplumsal, kültürel ve kentsel problemlerin önüne geçilebildiği bir yaklaşımdır. Kentsel dönüşüm projeleri ile kentin kentleşme sürecinde artan nüfusuna cevap verecek yeni konutların yapılması, kullanım ömrünü tamamlamış binaların yenilenmesi, kentin büyüme yönüne, coğrafi özelliklerine ve afet risklerine göre yeniden planlanması amaçlanmaktadır. Kentsel dönüşüm projelerinin bir diğer amacı ise alanda yaşam kalitesini yükseltirken, ekolojiye ve bölge halkının kültürüne dayalı planlama yaparak halk memnuniyetini ön planda tutulmasıdır.

Türkiye'de kentsel dönüşüm projesi çalışmalarına son 50 yılda hız verilmiş özellikle Çevre ve Şehircilik Bakanlığı'nın konuya verdiği önem ve destek sayesinde birçok ilde örnekleri artmıştır. Bu projeler özellikle kentsel yoğunluğu fazla olan kentlerde çöküntü alanlarının iyileştirilmesi ve yenilenmesi için sıklıkla kullanılan projeler olmuşlardır. Bu çalışmada sırasıyla kentsel dönüşüm kavramıyla anlatılmak istenenlere ve kentsel dönüşümün sürdürülebilir kent ideolojisiyle ilişkisine değinilmiştir. Sonrasında kentsel dönüşüm ile kentlerde amaçlanan değişim ve düzenlemelere yer verilmiştir. Kentsel dönüşüm projelerinde bulunması gereken peyzaj özellikleri belirtildikten sonra Niğde Merkez İlçesi'nde bulunan ve yapım aşamasında olan Efendibey Kentsel Dönüşüm Projesi peyzaj planlaması irdelenmiştir. Çalışmanın sonuç bölümünde ise Efendibey Kentsel Dönüşüm Projesi'nin peyzaj mimarlığı tasarım kriterlerine uygunluğu ortaya konulmuştur.

\section{MATERYAL ve YÖNTEM}

$\mathrm{Bu}$ araştırmanın ana materyalini Niğde Kenti Efendibey Kentsel Dönüşüm Projesi oluşturmaktadır. Araştırmada Niğde kenti için bir ilk niteliği taşıyan Efendibey Kentsel Dönüşüm Projesi' nin peyzaj tasarım ve planlama ilkeleri açısından değerlendirilerek kentleşme sürecini yaşayan Niğde kenti için bir örnek teşkil etmesi amaçlanmıştır. Çalışmada;

- Niğde Belediyesi'nden alınan imar planları,

- Efendibey, Şehitler ve Şahinali Mahallelerinin çalışmadan önceki fotoğrafları,

- Efendibey Kentsel Dönüşüm Projesi oturum planı, 
- Alanda 2 ada için geliştirilmiş plantasyon paftaları,

- İlgili resmi kurum ve kuruluşlardan elde edilen veriler,

- Efendibey Muhtarlığı ile yapılan görüşmeler,

- Yüklenici firma ile yapılan görüşmeler,

- Alan fotağrafları materyal olarak kullanılmıștır.

Çalışmada kentsel dönüşüm kavramının açıklanması için literatür taraması yapılarak elde edilen veriler değerlendirilmiştir. Sonrasında kentsel dönüşümün Türkiye'deki gelişimini ortaya koymak amacıyla, 1966 yılında Gecekondu Yasası ile başlayan kentsel dönüşüm (yenileşme) hareketinin daha sonraki dönemlerdeki gelişmesi ile ilgili yasalar araştırılarak ortaya konulmuştur. Çalışmanın bu aşamasında incelenen yasalar sırasıyla;

- 775 Sayılı Gecekondu Yasası,

- 5366 sayılı Yıpranan Tarihi ve Kültürel Taşınmaz Varlıkların Yenilenerek Korunması ve Yaşatılarak Kullanılması Yasası

- Belediye Yasası,

- Dönüşüm Alanları Hakkındaki Yasa Tasarısı,

- Kuzey Ankara Girişi Kentsel Dönüşüm Projesi Yasası,

- Orman Köylülerinin Kalkınmalarının Desteklenmesi ve Hazine Adına Orman Sınırları Dışına Çıkarılan Yerlerin Değerlendirilmesi,

- Hazine'ye Ait Tarım Arazilerinin Satışı Hakkındaki Yasa,

- Afet Riski Altındaki Alanların Dönüştürülmesi Hakkındaki Yasa'dır.

\section{KENTSEL DÖNÜŞÜM KAVRAMI}

Kent, nüfus artışı ile belirli noktalarda yoğunlaşan insan topluluklarının zanaat ve ticaretle gelişip, farklılaşması, çeşitlenmesi, iş kolları, sanat ve eğitimle değişmesi, örgütlenme ve uzmanlaşmanın yaygınlaşması, etik, kimlik, kavram ve kurallarının oluşumu gibi olguların bütününü ifade eder (Kaya, 2009).

Toplumların geçmişten getirdikleri kültürel özellikleri, gelişmişlik düzeyleri, sosyal eğilimleri, ekonomik durumları gibi özellikleri bölge coğrafyasının ve mevcut ekolojik parametrelerin etkisiyle şekillenerek kentin fiziki ve sosyal formunu oluşturmaktadır. Hızlı nüfus artışı, kırdan kente göç fazlalaşması gibi nedenlerle artan kent nüfusu zamanla kent üstünde yoğun bir baskı oluşturmakta ve kent kaliteli yaşam sürülen mekanlar olmaktan uzaklaşmaktadır. Ancak özellikle son elli yılda kaynakların sürdürülebilirliği kavramının yaygınlaşması ve gelişen teknolojinin de yardımıyla kentleşme hareketlerinde görünen farklılıklar zamanla kentin doğal kaynaklarına saygılı kentleşme kavramlarıyla örtüşmüştür. Tüm bunların yanında kentin sürekli değissen dinamik bir yapıda olması, doğal afetler, sanayileşme, göç gibi etkenlerle sürekli değişim göstermesi kent üstündeki baskıyı arttırarak sürdürülebilir kaynak yönetimini zorlaştırmaktadır. Kentlerin çeşitli nedenlerle yaşadığı değişimi ifade eden kentsel dönüşüm/yenileme kavramı, farklı şekillerde tanımlansa da en genel tanımıyla, farklı nedenlerden dolayı zaman içinde eskimiş, terkedilmiş, değer kaybına uğramıș ve köhneleşme eğilimine girmiş olan kent alanlarının günün sosyo-ekonomik ve fiziksel koşullarına uygun olarak yeniden canlandırılması ve kente kazandırılmasını ifade eder. Kent yenileme ihtiyacı kent içindeki tarihi bir yerleşme, işlevini yitirmiş bir sanayi alanı veya pek çok sosyal ve mekansal sorunu barındıran bir konut alanında veya hızlı ve sağlıksız gelişen kentlerde ortaya çıkan, yasadışı yapılaşma, ulaşılabilirlik, sağlıksız ve yetersiz altyapı arzı, doğal afetler gibi sorunlara çözüm bulma ihtiyacından doğabilir (Genç, 2008).

Kentsel dönüşümü; zamanla yıpranmış olan kent merkezinin çöküntü alanı haline gelmesini önlemek için mimari bir koruma yöntemi ve yoğun konut ihtiyacına çözüm bulmanın bir yolu olarak kentsel gelişme bağlamında ele alanların yanında (Çubuk, 1998), kentte olağan olarak gelişen dönüşüm ya da sıradışı sebeplerden kaynaklanan dönüşüm olarak ikiye ayıranlar da 
Niğde İli Efendibey Kentsel Dönüșüm Projesi'nin Peyzaj Mimarlı̆̆ı Açısından İrdelenmesi bulunmaktadır (Cundy, 1979; Gaffney, 1989; Özden, 2000; Genç, 2008). Kentsel dönüşüm ile kentin belirli bölümleri nitelik değiștirmekte ve yapısal değișime uğramaktadır (Tekeli, 2003). Bu süreci, her ülkenin özel koşullarını göz önüne alarak incelemek gerekmektedir. Ülkelerin içinde bulundukları kültürel ve sosyal gelişmişliğin yanında ekonomik gelişmişlikleri de farklı kentsel dönüşüm dinamiklerinin ortaya çıkmasına neden olmaktadır (Köktürk, E. ve Köktürk, E. 2007).

\subsection{Kentsel Dönüşümün Başlıca Amaçları}

Kentsel dönüşümün esas amaçları; fiziksel ve çevresel amaçlar, ekonomik amaçlar, sosyal amaçlar ve kültürel amaçlar olmak üzere dört başlık altında ele alınmaktadır (Yaman, 2014). Bunlar sirasılyla;

\subsubsection{Fiziksel ve Çevresel Amaçlar;}

- Kentlerde önemli sorunlardan biri olan gecekondu yapımının önlenmesi ve mevcut gecekonduların ortadan kaldırılarak yerine çağdaş bir kent görünümünün oluşturulması, gecekondu sahiplerinin de desteğini alacak şekilde yeni alternatifler sunan kentsel dönüşüm uygulamalarının planlanması,

- İşlevini yitirmiş çöküntü alanlarındaki konutların yerine daha kaliteli ve yaşanabilir konutlar yapılması, altyapı sorunlarının tamamen giderilmesi, toplumsal bütünleşmenin sağlanması; çevresel kalitenin veya çevre dengesinin yitirildiği alanlarda bu dengenin yeniden sağlanması,

- Çevresel koşulların iyileştirilerek, insanların daha huzurlu ortamlarda yaşamalarının sağlanması, kentsel yaşam kalitesi artırılarak, insanların yaşam alanlarıyla bütünleştirilmesi.

\subsubsection{Ekonomik Amaçlar}

- Ekonomik yaşamın tam anlamıyla yeniden canlandırılması, kentsel huzur ve yaşam kalitesini artıran bir ekonomik kalkınma yaklaşımının ortaya konulması,

- Kentsel müdahale edilen alanlarda, iş imkânları, istihdam ve ticari cazibe alanları yaratılması ve yatırımclların bu bölgelere çekilmesi,

- Kentsel refah ve yaşam kalitesini artırıcı bir anlayışla ekonomik dinamiklerin harekete geçirilmesi.

\subsubsection{Sosyal Amaçlar}

- Kentsel dönüşüm alanlarında toplumsal bir sorun haline gelen çöküntü alanları tespit edilerek, toplumsal sorunların bir an önce çözülmesi,

- Kentsel dönüşüm uygulamalarında özellikle sosyal boyutlar gözetilerek, bölge insanlarının mağdur edilmemesi,

- Kentsel alanların etkin biçimde kullanımına ve gelişigüzel kentsel büyüme anlayışına son verecek yeni stratejilerin planlı bir biçimde ortaya konulması.

\subsubsection{Kültürel Amaçlar}

- Kentlerin kültürel mirasının gelecek nesillere aktarılması, doğal, tarihi ve kültürel dokunun korunması,

• Kentlerin özgünlüklerini kaybetmeden kimliklerini koruyan kentsel dönüşüm uygulamalarının tercih edilmesi,

- Doğal, kültürel ve tarihi zenginlikleri yaşatan kentsel dönüşüm uygulamalarında kentsel yapılarda sürdürülebilirliğin gözetilmesi şeklindedir.

\section{TÜRKIYY'DE KENTSEL DÖNÜŞÜM PROJELERİ}

Dünya üzerinde kentsel dönüşüm projelerinin kentsel hayatı düzenleyici ve yaşam standartlarını iyileştirici örneklerinin bulunması ve özellikle nüfus yoğunluğu çok olan illerin gecekondulaşma, yozlaşma, çevresel bozulma ve ekonomik, toplumsal ve kültürel bunalımlarla boğuşur hale gelmesi Türkiye'de de kentsel dönüşüm projelerinin gündeme gelmesine sebep olmuştur. 
Ozellikle Avrupa Birliği'ne katılım sürecinde sağlanması zorunlu kriterler arasında çevrenin iyileştirilmesi şartı Türkiye'nin bu konu üzerinde dikkatle durmasına sebep olmuştur.

$\mathrm{Bu}$ amaçla ülkemizde geliştirilen birçok yasa bulunmaktadır. Bu yasaların ilki sayılabilecek olan yasa; 1966 yılında yürürlüğe giren Gecekondu Yasası'dır. Bu yasa ile mevcut gecekonduların ıslahı, tasfiyesi, yeniden gecekondu yapımının önlenmesi ve bu amaçlarla alınması gereken tedbirler (Anonim a, 2015) ortaya konulmuş olup kentsel dönüşümün şartları hakkında herhangi bir bilgi ortaya konulmamıştır. Daha sonra kentleşmenin getirdiği problemlerin önüne geçilmesi amacıyla Toplu Konut Yasaları, İmar Yasası, Büyükșehir Belediye Yasası gibi yasalar yürürlüğe girmiștir. Ancak 5366 sayılı Yıpranan Tarihi ve Kültürel Taşınmaz Varlıkların Yenilenerek Korunması ve Yaşatılarak Kullanılması Yasası ile yıpranan ve özelliğini kaybetmeye yüz tutmuş; kültür ve tabiat varlıklarını koruma kurullarınca sit alanı olarak tescil ve ilan edilen bölgeler ile bu bölgelere ait koruma alanlarının, bölgenin gelişimine uygun olarak yeniden inşa ve restore edilerek bu bölgelerde konut, ticaret, kültür, turizm ve sosyal donatı alanları oluşturulması, tabii afet risklerine karşı tedbirler alınması, tarihi ve kültürel taşınmaz varlıkların yenilenerek korunması ve yaşatılarak kullanılması ile ilgili esas ve usulleri düzenlemek (Anonim b, 2015) amaçlanmış ve kent parçalarının yeniden kullanılmasına dair adımlar yasalarla belirlenmeye başlanmıştır.

Sonrasında Belediye Yasası, Kuzey Ankara Girişi kentsel Dönüşüm Projesi Yasası, Dönüşüm Alanları Hakkındaki Yasa Tasarısı, Orman Köylülerinin Kalkınmalarının Desteklenmesi ve Hazine Adına Orman Sınırları Dışına Çıkarılan Yerlerin Değerlendirilmesi, Dönüşüm Projeleri Özel Hesabi Gelir, Harcama, Kredi Ve Kaynak Aktarimi Yönetmeliği, Afet Riski Altindaki Alanlarin Dönüştürülmesi Hakkinda Kanunun Uygulama Yönetmeliği ile Hazine'ye Ait Tarım Arazilerinin Satışı Hakkındaki Yasa, Afet Riski Altındaki Alanların Dönüştürülmesi Hakkındaki Yasa gibi yasalarla farklı kullanım amaçları olan ancak koruma altına alınarak toplum hizmetine sunulabilecek alanlarla ilgili düzenlemeler içeren yasalar geliştirilmiştir. Adı geçen yasalar peyzaj mimarlığı planlama ve tasarım kriterleri açısından irdelenecek olursa, yasaların tümünde tabiat varlıklarının korunmasına önem verildiği ve bu alanların bölgenin gelişimine uygun olarak yeniden inşa ve restore edilmesinin uygun olacağı görüşü yer almaktadır. Bunun dışında özellikle kentsel dönüşüm projelerinin peyzaj düzenlemeleri için getirilmiş ayrıntılı bir düzenleme bulunmamaktadır. Ancak Kuzey Ankara Girişi Kentsel Dönüşüm Projesi Yasası'nda yasanın amacı, kuzey Ankara girişi ve çevresini kapsayan alanlarda kentsel dönüşüm projesi çerçevesinde fiziksel durumun ve çevre görüntüsünün geliştirilmesi, güzelleştirilmesi ve daha sağlıklı bir yerleşim düzeni sağlanması ile kentsel yaşam düzeyinin yükseltilmesi olarak ayrıntı verilmiş ve kentsel iyileştirme amaçlı dönüşecek alanlar için peyzajın ne denli önemli olduğunu ortaya koymuştur (Anonim c, 2015).

Ülkemizde birçok kentte olduğu gibi Niğde kenti de özellikle köylerinden göç alan bir kenttir. Özellikle kent merkezine yakın ve boş alanların yoğun göç alması ile kentte çarpık kentleşme ve çöküntü alanları kendini göstermeye başlamıştır. Niğde Efendibey Mahallesi de kent merkezine çok yakın çöküntü alanlarından biridir. Bu sağlıksız gelişmenin önüne geçilmesi için Niğde Belediyesi tarafından 2012 yılında Efendibey Kentsel Dönüşüm Projesi hayata geçirilmiştir.

\subsection{Niğde İli Efendibey Kentsel Dönüşüm Projesi}

Niğde ili merkez ilçesi sınırları içinde bulunan Efendibey Mahallesi 37,975948 enlem ve 34,681824 boylamda yer almaktadır (URL 1). Özellikle kent merkezine olan yakınlığı mahallenin kente göç eden nüfus tarafından yerleşim yeri olarak tercih edilmesine sebep olmaktadır. Ancak yapılaşma şeklinin kentin geleneksel yerleşme dokusu ve yakınında bulunan TOKİ konutları ile büyük tezatlık yaşaması, kentsel yaşam kalitesinin çok düşük olması ve kentin görsel imajını zedelemesinden dolayı Niğde Belediyesi 2012 yılında Efendibey, Şehitler ve Şahinali Mahallelerini kapsayan bir kentsel dönüşüm projesi hayata geçirmişlerdir. Projenin Niğde kenti için bir ilk olması ve kent merkezine olan yakınlığı projenin önemini arttırmaktadır. 
Niğde İli Efendibey Kentsel Dönüșüm Projesi'nin Peyzaj Mimarlığı Accısından İrdelenmesi

Efendibey Muhtarlığı ile yaplan ikili görüşmeler sonucu kentsel dönüşüm projesinin başlamasından önce Efendibey Mahallesi'nde yaklaşık 18.000 nüfusun yaşadığını, 4 adet çocuk oyun alanının, 1 adet pazar yerinin, 1 adet cami ve 2 adet ilköğretim okulunun bulunduğu, lise ve anaokulunun bulunmadığı bilgisine ulaşılmıștır. Şehitler Mahallesi'nde ise projeden önce yaklaşık 4500 nüfusun bulunduğu, mahalle sınırları içinde çocuk oyun alanının, pazar yerinin, anaokulunun, ilköğretim okulunun ve lisenin bulunmadığı belirtilmiştir. Mahallede 1 adet cami bulunmaktadır. Proje alanın kentsel dönüşüm projesinin başlamasından önceki durumu Şekil 1'de gösterilmektedir (Anonim d, 2015).

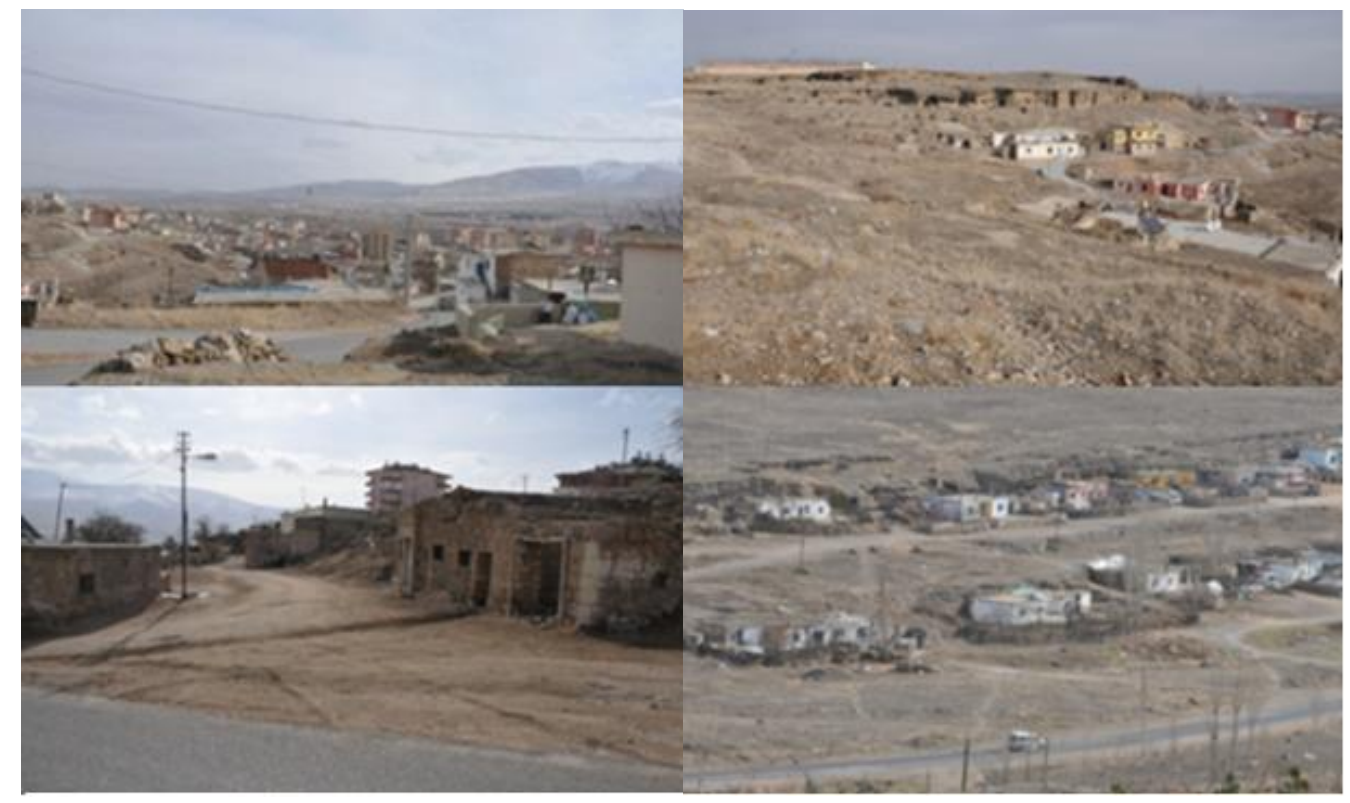

Şekil 1. Alanın kentsel dönüşüm projesi başlamasından önceki görünümü

Niğde Belediyesi'nin hazırlatmış olduğu proje 1.210 .000 metrekarelik bir kentsel alanı kapsamaktadır. Dönüşüm çerçevesinde, değişik alanlarda 6.000 adet konut, $240.000 \mathrm{~m} 2$, rekreasyon alanı, $120.000 \mathrm{~m} 2$, kent parkı, 3'ü korunan olmak üzere 5 adet cami; kültür, alışveriş ve iş merkezleri, sağlık ocağı, açık spor alanları, lise, amfiteatrlar, 2 adet ilköğretim okulu ve meydanlar inşa edilecektir (Gökçe ve Akçaözoğlu, 2012). Şekil 2'de alanın kentsel dönüşüm projesi başlamadan önceki durumu ve proje sonlandırıldıktan sonraki durumu gösterilmektedir (Anonim d, 2015).
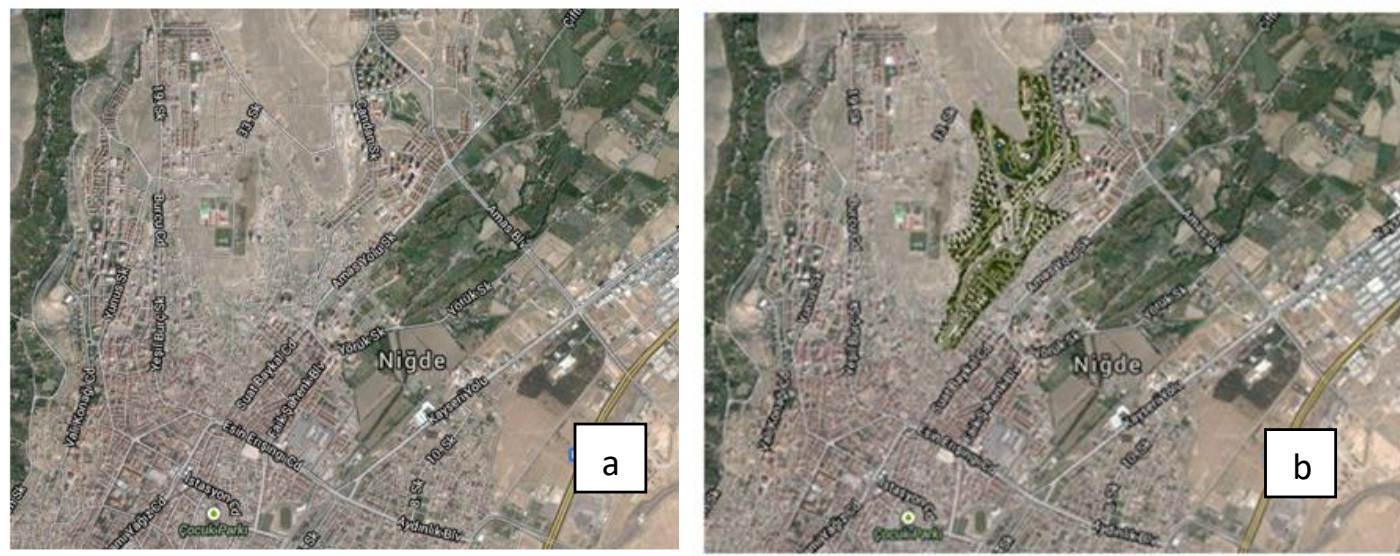

Şekil 2. Alanın kentsel dönüşüm projesi başlamadan; a) önceki durumu, b)sonraki durumu 
4.1.1. Efendibey Kentsel Dönüşüm Projesi Rekreasyon Alanlarının Peyzaj Mimarlığı Açısından Ele Alınması

Proje alanının \%89'unun rekreasyon alanı olarak ayrılması, alan içindeki yeşil alan kullanımının (çocuk oyun alanı, spor sahaları, yürüyüş parkurları vb.) çeşitlendirilmesi, naturel formda kullanılmış su öğesi alan içinde yaşayacak insanların yaşam standartlarını yükselten etkenlerden bir kaçıdır. Farklı bir bakıș açısıyla yaklașık 6000 konuttan oluşan böyle bir kentsel dönüşüm projesinin içinde konut oturum alanının yaklașık sekiz katı büyüklügünde rekreasyon alanının kullanılması alanın doğaya entegrasyonunu kolaylaştıracaktır. Bahsi geçen rekreasyon alanı içine avm ve ticaret merkezi gibi yapısal ağırlıklı alanlar girse de bu alanların yakın çevrelerin de yeşil alanların yoğun olarak kullanılması alan içindeki beton etkisini azaltacaktır.

Proje alanın da bulunan farklı topoğrafik özellikler alanı çekici kılmaktadır. Ancak plansız ve bilinçsiz gelişen yerleşimler alanın bu etkisini gizlemektedir. Proje alanının eğiminin yer yer değişmesi alan içinde yol güzergâhlarında farklılık yaratılmasına olanak vermiştir. Alan içinde özellikle ana arter lineer kullanılmış yapı adalarında dolaşım mesafesini arttırması, sürprizli manzara olanaklarının yaratılması için yumuşak kurplardan faydalanılmıştır (Şekil 3) (Anonim d, 2015, TOKİ, 2015).

Kentsel dönüşüm projesine rekreasyon ve park alanları açısından bakıldığında alan kendi içinde giriş alanı meydan çalışması ('kent park' olarak adlandırılan büyük yeşil alan parçası), yapı adaları içi yeşil alan çalışmaları, yapı adaları arası yeşil alan çalışmaları, avm, kültür merkezi, ticaret merkezi, butik otel yakın çevresi yeșil alan çalışmaları, okul, sağlı birimi yakın çevresi yeşil alan çalışmaları, kavşak ve refüj çalışmaları, spor merkezi, amfi tiyatro ve otopark çalışmaları olarak ayırabilmektedir. Bu kullanımlar haricinde proje de hobi bahçesi, çatı bahçesi, piknik alanı gibi özel kullanımlara yer verilmemiştir.

Alanın önemli bir bakı noktasına yerleștirilen ve proje üzerinde 'kent parkı' olarak adlandırılan park alan içinde ayrılmış en büyük parktır. İçinde doğal formlara sahip bir su yüzeyi bulundurmaktadır. Bu su yüzeyi ile bütünleşmiş amfi tiyatro ve su yüzeyinin içine doğru uzanan sert zeminler ve köprülerle su hareketlendirilmiştir. Alan içinde ki topoğrafik yapının bu yeşil alan ile bütünleștirilmesi projenin başarılı noktalarından biri olmuştur. Yeşil alanın sakinleştirici etkisi ve butik otele yakınlığı alan içinde ki butik otel kullanıcılarının da bu alanı kullanmasına olanak sağlayacaktır. Yaklaşık alanı $160 \mathrm{~m} 2$ olan bu alanın içinde ki su yüzeyi alanı yaklaşık 26.360 m2'dir. Kalan $133.640 \mathrm{~m} 2$ alanda ise yeșil alan uygulamaları, yollar, oturma alanları vb. kullanılmıştır (Şekil 4) (Anonim d, 2015, TOKİ, 2015).

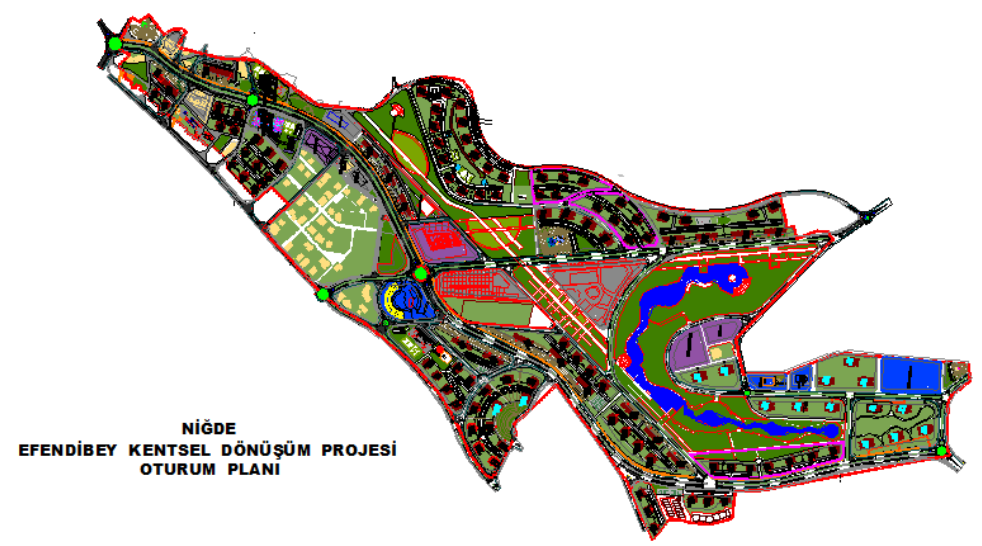

Şekil 3. Niğde Efendibey Kentsel Dönüșüm Projesi oturum alanı 


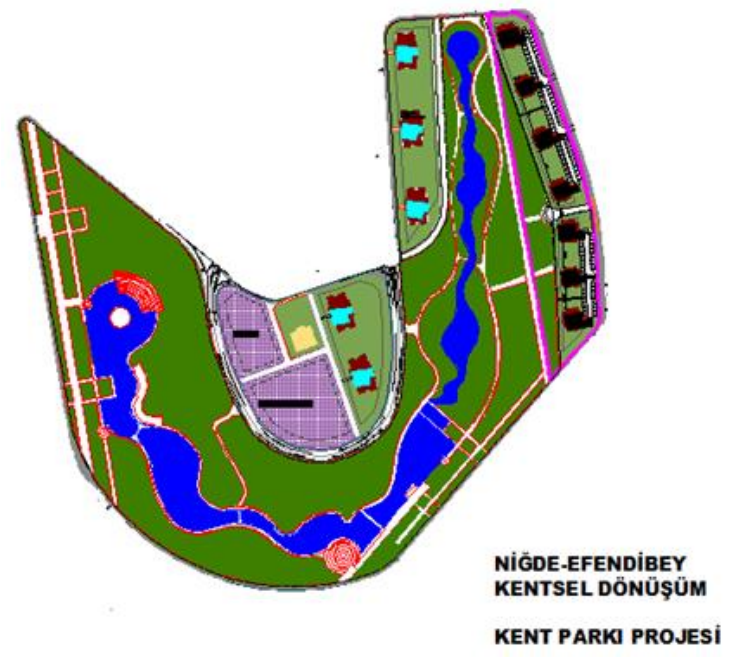

Şekil 4. Niğde Efendibey Kentsel Dönüşüm Projesi-kent parkı

Belediyeden elde edilen oturum planı dikkate alındığında yapı adası içi ve yapı adaları arası yeşil alanların henüz hepsinin detaylandırılmadığı görülmektedir. Bu açıdan kullanılan bitkisel materyal, yapısal materyalin tümü, kullanımların konumlandırılması gibi detaylar yorumlanamamaktadır. Ancak detaylandırılan örnek bir yapı adası içinde farklı üç adet çocuk oyun alanı bir adet basketbol, bir adet mini futbol sahasının ve koşu parkının tasarlandığı görülmektedir. Alan içinde ki konumlarının otopark için ayrılan yola yakınlığı dikkat çekse de bu sakıncalı durumun yapısal ve bitkisel materyalle önüne geçilmesi mümkündür (Şekil 5) (Anonim d, 2015, TOKİ, 2015).

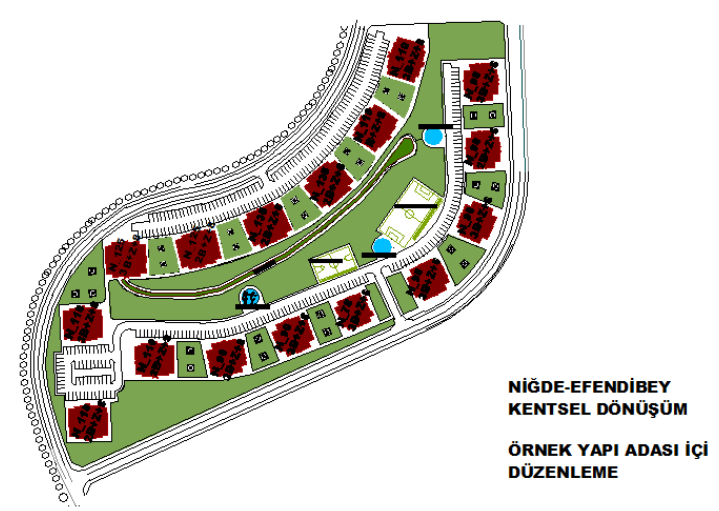

Şekil 5. Niğde Efendibey Kentsel Dönüşüm Projesi-örnek yapı adaları

Yapı adaları içinde ki otopark hesabı 1 konut için 1 otopark esasına dayalı olarak yapılmıştır. Arazinin izin verdiği adalarda gerekenden fazla otopark kullanılmıştır. Alan içinde ki her farklı kullanımın (okul, cami, otel, pansiyon vb.) kendine ait, kapasitesiyle orantılı bir otoparkı bulunmaktadır. Belediyeden alınan bilgilere göre adalar içinde ki otopark sayısı aşağıda belirtilmiştir (Tablo 1).

Alan içinde sadece 'kent parkı' olarak nitelendirilen alanda su kullanımı vardır. Toplam yüzey alanı $26.360 \mathrm{~m} 2$ olan su yüzeyinin bu ölçekte ki bir kentsel dönüşüm projesi için yetersiz olacağı düşünülmektedir. Yapı adaları ve bina yakın çevresi detay projelerin de tasarlanacak su yüzeyleri kullanıcı için rahatlatıcı etki yaratacaktır. 
Tablo 1. Niğde Efendibey Kentsel Dönüșüm Projesi-Otopark Hesabı

\begin{tabular}{ccc}
\hline Ada Numarasi & Konut Sayisi & Otopark Sayisi \\
\hline 1 & 558 & 559 \\
\hline 2 & 302 & 302 \\
\hline 3 & 228 & 228 \\
\hline 4 & 492 & 492 \\
\hline 5 & 252 & 287 \\
\hline 6 & 162 & 228 \\
\hline 7 & 88 & 88 \\
\hline 8 & 52 & 56 \\
\hline Toplam & 2134 & 2240 \\
\hline \hline
\end{tabular}

3194 sayılı İmar Kanunu'nda geçen kentsel standartlarda kişi başına düşmesi gerekli olan yeşil alan miktarı 10 m2'dir. Efendibey Kentsel Dönüşüm Projesi'nde kişi başına düşen yeşil alan miktarı da $10 \mathrm{~m} 2$ olarak hesaplanmıştır. Türkiye'de birçok ilimizde ve hatta Niğde kent merkezinde de sağlanamayan bu oranın bu projede sağlanabiliyor olması projenin başarılı noktalarından biridir. Ayrıca kent merkezine çok yakın olan alanın sahip olduğu açık yeşil alan miktarının kentin ihtiyaç duyduğu rekreatif faaliyetlere ve ekolojik iyileşmeye de katkısı bulunacaktır.

\subsubsection{Projede Bitki Kullanımı}

Bu denli kapsamlı bir proje de kullanacak bitki materyalinin alanın tüm çevresel değerleri üzerine etkisi olacak ve bölge içinde ayrı bir mikroklimatik alan yaratılacaktır. Bu büyüklükte ki bir projede bitkinin her türlüsüne (ağaç, ağaççı, çalı, yer örtüsü, mevsimlik çim alan, su bitkisi) yer verilebilir. Oluşturulacak gölge alanlar, çim alanlar, renkli çiçek parterleri, perdeleyici ve sınırlayıcı bitkiler, otopark ağaçlandırılmaları, soliter ve grup halinde kullanılacak bitki gösterileri alana hareketlilik katarken alanın işlevselliğini de arttıracaktır. Belediyeden ve yüklenici firmadan alınan bilgilere göre alan içinde sadece 2 yapı adasının bitkisel projesi hazırlanmıştır (Şekil 6) (Anonim d, 2015, TOKİ, 2015). Bu projelerde kullanılan bitkiler;

\section{Yapraklı bitkiler}

Prunus mahalep (Mahlep), Tilia tomentosa (Gümüşi ıhlamur), Prunus ceracifera atropurpurea (Kırmızı yapraklı süs eriği), Platanus orientalis (Çınar), Acer negundo var. Atro. (Kırmızı yapraklı akçaağaç), Fraksinus excelsior (Dişbudak), Cryptomeria japonica (Alev ağacı), Aesculus carnea (At kestanesi), Morus pendula (Așilı ters dut).

\section{Ibreli bitkiler}

Abies nordmandiana (Doğu Karadeniz göknarı), Pinus nigra (Kara çam), Picea pungens (Ladin), Cup.arizonaci var. Skyrocket (Mavi skyrocket), Phyracantha coccinea (Ateş dikeni).

Çalı ve sarılıcı bitkiler

Jasminium officinalis (Beyaz çiçekli yasemin), Syringa vulgaris (Aşıll leylak), Juniperus horizontalis (Yayılıcı ardıç), Pitossporum tobira (Pitosporum) şeklindedir.

Seçilen bitkilerin yapraklı ve ibreli seçilen çeşitleri fonksiyonellikleri ve alana katacakları estetik değerler bakımından uygun olup, bölgenin ekolojik koşullarına uygun bitkilerdir. Ancak çalı ve sarılıcı grubu bitkiler arasında yer alan Jasminium officinalis (Beyaz çiçekli yasemin) ve Pitossporum tobira (Pitosporum)'un ekolojik istekleri göz önünde bulundurulduğunda alanın ekolojik özelliklerinin bu bitkiler için uygun bir yaşam alanı olmadığı görülmektedir. 

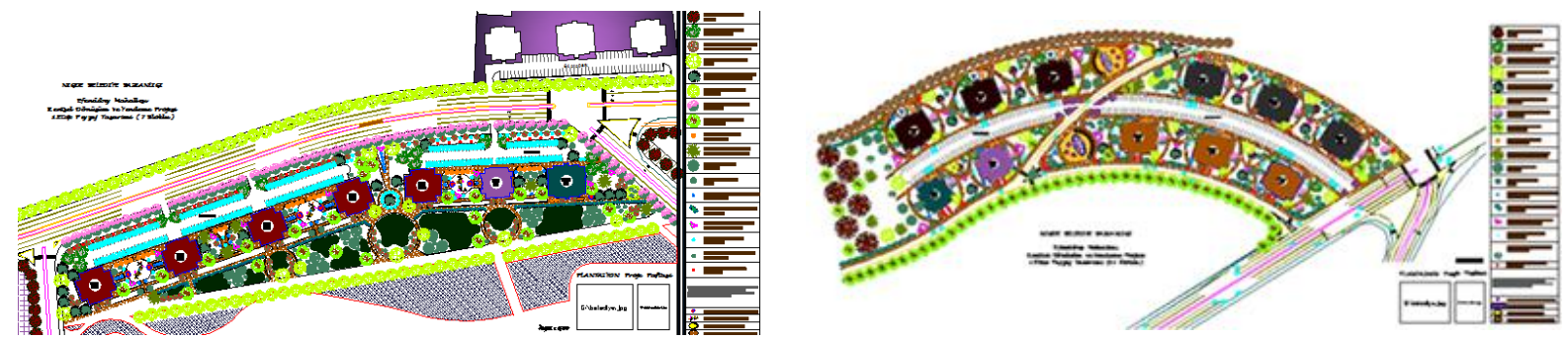

Şekil 6. Niğde Efendibey Kentsel Dönüşüm Projesi-Örnek Bitkilendirme Çalışması

\subsubsection{Projede Kentsel Sosyal Donatıların Kullanımı}

Proje alanı içerisinde bir adet butik otel, bir adet avm, bir adet kültür merkezi, ticari alanlar çeşitli gösteriler için amfi tiyatro, beş adet camı ( 3 adet eski, 2 adet yeni), 2 adet sağlık ocağı, 3 adet ilk öğretim okulu, 1 adet lise, kapalı spor salonu alanı ve çeşitli büyüklüklerde restaurant, cafe ve üstü açık ve kapalı olarak tasarlanan oturma alanları bulunmaktadır. Bu alanların bölgede uzun sürede ihtiyaç duyulan sosyal hayatın canlandırılması amacına hizmet edeceği düşünülmektedir. Bu kullanımların yakın çevrelerinde kendilerine ait peyzaj alanlarının olması ve otopark sıkıntısının yaşanmaması yapıların her mevsim, her yaştan kullanıcıya hizmet vermelerini sağlayacaktır.

Alan içinde bulunması gereken meydanlar, otoparklar, bisiklet yolları, yaya yolları, fitness alanları, çocuk oyun alanları, gazebo gibi oturma alanları, büfeler, su üstü kullanımları (iskele-ada), wc'ler, danışma merkezleri, güvenlik binaları vb. kullanımların hepsi sosyal donatı kapsamına girmektedirler. Ancak oturum planı üzerinde tümünün gösteriminin yapılmamasından dolayı sadece projede bulunanlar irdelenmiștir. Oturum planında yer alan bina kütlesi olarak alanda homojen dağılan, belli bir noktada kümeleşme yaratmayan kullanımların $25 \mathrm{~m}$ ve $35 \mathrm{~m}$ genişlikteki ana caddelerle ve daha dar bağlantı yollarıyla birbirleriyle bağlantısı sağlanmıștır. Alanın manzara hâkimiyetinin olduğu noktasına butik otelin yerleştirilmiş olması gelen turistler için avantaj sağlarken alanın yerli kullanıcısı için bir olumsuzluk oluşturmaktadır. Alan içinde ki kullanımlar ve alan içindeki görünümleri Şekil 7 ve Şekil 8'de görülmektedir (Anonim d, 2015).

\subsubsection{Projede Peyzaj Donatı Elemanlarının Kullanımı}

Kullanıcıların yaratılan açık yeşil alanları aktif olarak kullanmasına olanak veren peyzaj donatı elemanları (kent mobilyaları, aydınlatma elemanları, çöp kutuları, yönlendirme levhaları) alan içinde homojen dağıtılmış, alanın mevsimsel özellikleri ile uyumlu işlevsel ve estetik olmalıdır. Alanın özellikle de genel kullanımı mekânlarının tüm kente hitap edeceği düşünülürse yoğun kullanıma ve vandalizme karşı dayanıklı malzemelerden seçilmesi gerekmektedir. Proje alanı donatı elemanlarının seçimi ve kullanımı hakkında geliştirilmiş bir projenin olmamasından dolayı bu kullanımların özellikleri irdelenememiştir.

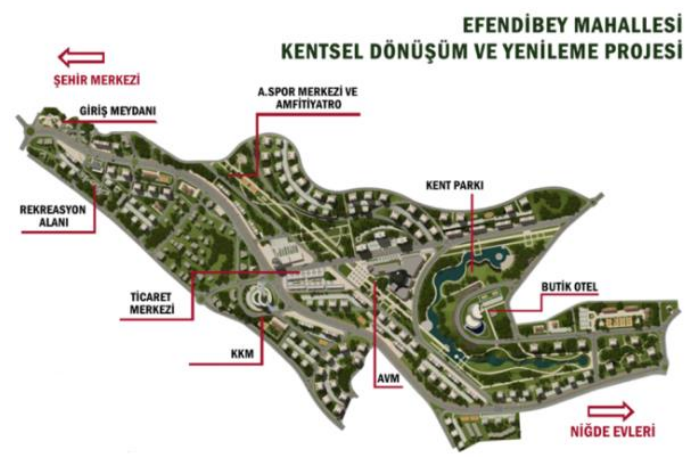

Şekil 7. Niğde Efendibey Kentsel Dönüşüm Projesi-Alan İçi Kullanımlar 


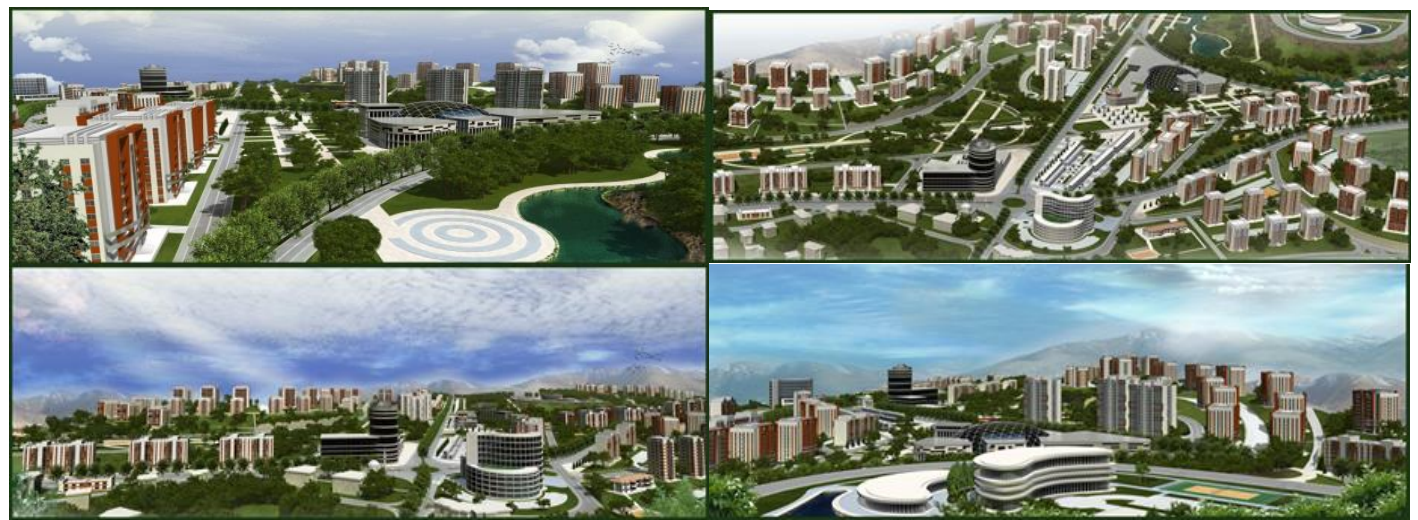

Şekil 8. Niğde Efendibey Kentsel Dönüşüm Projesi-Alan İçi Kullanımların Görünüşleri

\section{SONUÇ}

Efendibey Mahallesi, Niğde merkezine yakınlığı ve alan içi topoğrafik özellikleri bakımından ayrıcalıklı bir alandır. Bu alanın kente göç ile gelen insanlar tarafından yapılan gecekondular ve kullanım ömrünü tamamlamış estetik olmayan binalar tarafından kentin çöküntü alanı haline gelmesinin önüne geçilmesi açısından başlatılan Efendibey Kentsel Dönüşüm Projesi hem alanda yaşayan halkın daha sağlıklı bir çevrede yaşaması hem de kentleşme sürecini yaşayan Niğde için bir örnek teşkil etmesi açısından oldukça önemlidir. Proje alanı için geliştirilen plan başlıkları ile kentte yaşayan halkın yaşam çevresini değiştirip halka kent hayatının getirdiklerini öğretirken, büyük yeșil alanları sayesinde kente değer katacaktır. Gelecekte bu tip yeșil alan oranlarının dünya standartlarında olduğu sağlıklı yaşam çevrelerinin Niğde kentinde çoğalması kurak bir kent imajında olan Niğde'nin yeşil bir kimlik kazanmasına yardımcı olacaktır. Ancak önemli olan bu alanların kentte birbirinden farklı kent parçaları olarak kalmayıp bütüncül bir plan yaklaşımı içerisinde ele alınabilmesidir. Kentin tarihinden getirdiği kültürel özelliklerinin ve geleneksel mimarisinin projeye katılabilmesi ve alan kullanıcılarının memnuniyetinin sağlanması projenin başarısını yükseltecektir. Bu çalışmanın yapılmasına alanın fotoğrafları ve projeleriyle destek veren Niğde Belediyesi ve Toplu Konut İdaresi Başkanlığı'na teşekkürlerimi sunarım.

Çalışma sonunda Efendibey Kentsel Dönüşüm Projesi'nde bulunan açık-yeşil alan sisteminin peyzaj mimarlığı ilkeleri açısından değerlendirilmesi sonucu elde edilen veriler Tablo 2'de verilmiștir.

Tablo 2. Efendibey Kentsel Dönüşüm Projesi’nde bulunan açık-yeşil alan sisteminin peyzaj mimarlığ ilkeleri açısından değerlendirilmesi

\begin{tabular}{|c|c|c|}
\hline \multirow{7}{*}{ 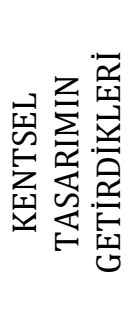 } & Kent ekolojisine katkı sağlanması & + \\
\hline & Kent kimliğini kuvvetlendirmesi & + \\
\hline & Kentte cazibe noktası oluşturması & + \\
\hline & Tasarlanan kütlelerin geleneksel mimari özelliklerine sahip olması & - \\
\hline & Kent için önemli değerlerin korunması (cami, tarihi konut) & + \\
\hline & Kırsaldan göç eden halka kentsel yaşam eğitiminin verilmesi & + \\
\hline & Tasarlanan kütlelerin fonksiyonel olması & + \\
\hline \multirow{4}{*}{ 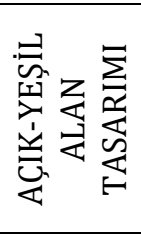 } & Kişi başı düşen yeşil alan miktarının dünya standardında olması & + \\
\hline & Kentin yeşil alanları ile bir bütünlük sağlanması & - \\
\hline & Alan içinde ki açık-yeşil alanların homojen dağılımı & + \\
\hline & $\begin{array}{l}\text { Kent ve bölge kullanıcısın farklı aktivitelere fırsat verilmesi, teşvik } \\
\text { edilmesi }\end{array}$ & + \\
\hline
\end{tabular}


Niğde İli Efendibey Kentsel Dönüșüm Projesi'nin Peyzaj Mimarlı̆̆ı Açısından İrdelenmesi

\begin{tabular}{|c|c|c|}
\hline & nin rekreasyon amaçlı ziyaretine olanak tanıması & + \\
\hline & Açlk yeşil alanlarla bina kütlelerin bütünlüğü & + \\
\hline & Alan içinde kesintisiz yeşil alan sağlanması & + \\
\hline \multirow{3}{*}{ 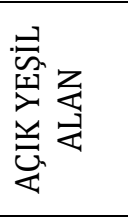 } & Bölgeye uygun bitki çeşidi seçimi (projesi tamamlanmış 2 yapı adası için) & + \\
\hline & $\begin{array}{l}\text { Bitkisel tasarımın estetik ve fonksiyonel olması (projesi tamamlanmış } 2 \\
\text { yapı adası için) }\end{array}$ & + \\
\hline & $\begin{array}{l}\text { Bitkilendirmenin homojen dağılımı (projesi tamamlanmış } 2 \text { yapı adası } \\
\text { için) }\end{array}$ & + \\
\hline \multirow{4}{*}{ • } & Su yüzeylerinin yeterliliği & \\
\hline & Su yüzeylerinin alan içinde ki homojen dağılımı & - \\
\hline & Alanda su öğesinin devamlılığının sağlanması & - \\
\hline & Alan içinde hareketli su kullanımı & - \\
\hline \multirow{8}{*}{ 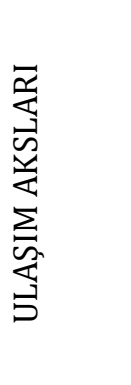 } & Ulaşım akslarının kademelendirilmesi & + \\
\hline & Alanda her alana tanımlı bir ulaşım aksının mevcudiyeti & + \\
\hline & Yaya açlk-yeşil alan ilişkisinin kuvvetlendirilmesi & + \\
\hline & Ana ulaşım akslarında yeşil kullanımı & + \\
\hline & Yaya öncelikli sirkülasyonunu desteklenmesi & - \\
\hline & Bisiklet öncelikli sirkülasyonun desteklenmesi & - \\
\hline & Otopark yeterliliği & + \\
\hline & Ulaşım ağının farklı manzaralara olanak vermesi & + \\
\hline \multirow{5}{*}{ 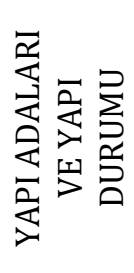 } & Yapı adalarının yapı yoğun olmaması & + \\
\hline & Ada içinde homojen yapı-yeşil alan dağılımı & + \\
\hline & Tek tip ada planlarının önüne geçilmesi & + \\
\hline & $\begin{array}{l}\text { Yapıların birbirinin güneşini, rüzgârını ve manzarasını kesmeyecek } \\
\text { şekilde yerleștirilmesi }\end{array}$ & + \\
\hline & Yapıların otoparkla ilişkisinin sağlanması & + \\
\hline \multirow{5}{*}{ 岕畓 } & Yaşam standardını yükseltecek sosyal ihtiyaçların alan içinde mevcudiyeti & + \\
\hline & Fonksiyon çeşitliliğin bulunması & + \\
\hline & $\begin{array}{l}\text { İnsanların arasında gruplaşmaya veya ayrılmaya (soylulaştırma) neden } \\
\text { olmaması }\end{array}$ & + \\
\hline & Niğde yerel kültürünü yaşatacak fonksiyonlara yer verilmesi & - \\
\hline & $\begin{array}{l}\text { Boş zaman aktivitelerinin içine sanatsal ve kültürel aktivitelerin girmesi } \\
\text { için alan sağlanması }\end{array}$ & + \\
\hline
\end{tabular}

\section{KAYNAKLAR}

Anonim a (2015). 775 Sayllı Gecekondu Yasası, Kabul Tarihi: 20 Temmuz 1966 Resmi Gazete ile Neşir ve İlânı: 30 Temmuz 1966 - Sayı: 12362.

Anonim b (2015). 5366 sayılı Yıpranan Tarihi ve Kültürel Taşınmaz Varlıkların Yenilenerek Korunması ve Yaşatılarak Kullanılması Yasası. Bakanlar Kurulu Karar Tarihi - No: 17/11/2005 - 2005/9668 Resmi Gazete Tarihi: 14/12/2005 Resmi Gazete Sayısı: 26023.

Anonim c (2015). 5104 Sayılı Kuzey Ankara Gırıșı Kentsel Dönüşüm Projesı Kanunu, Kanun Numarası: 5104 Kabul Tarihi: 4/3/2004, Yayımlandığı R.Gazete: Tarih : 12/3/2004 Sayı :25400 Yayımlandığı Düstur: Tertip : 5 Cilt : 43.

Anonim d (2015). Niğde Belediye Başkanlı̆̆g, Niğde Belediyesi İmar ve Şehircilik Müdürlüğü.

Cundy, F. C. (1979). Scenario for a housing improvement program in disaster-prone Areas. Disasters. III, 3 (253-257). 
Afet ve Risk Dergisi Cilt: 1 Sayı: 2, 2018 (93-105)

Filiz Cetinkaya KARAFAKI

Çubuk, M. (1998). Türkiye ve kültür mirası zenginligini koruma için savunma. Çağdas Kentsel Kültür

Mirası Kentsel Koruma-Yenileme-Kentsel İyilestirme. İstanbul: Mimar Sinan Üniversitesi Yayını. 1-8.

Genç, F. N. (2008). Türkiye'de kentsel dönüsüm: mevzuat ve uygulamaların genel görünümü. Yönetim ve Ekonomi Dergisi, 15 (1). 116-130. ISSN:1302-0064.

Gökçe, M. V. ve Akçaözoğlu, S. (2012). Niğde Efendibey Mahallesi kentsel dönüşüm projesinin kentin dinamikleri açısından değerlendirilmesi. 24. Uluslararası Yapı Yaşam Kongresi Türkiye, Bursa, 53-162.

Gaffney, M. (1989). How to revive a dying city. ORER Letter, III, 3 (1-6).

Karadağ, A. ve Miroğlu, G. (2012). Bayraklı kentsel dönüşüm projesi üzerine coğrafi değerlendirmeler. Türk Coğrafya Dergisi, 57 (21-32). Basllı ISSN 1302-5856.

Kaya, E. (2009). Kentsel dönüşüm projeleri ve halk katılımı. Toplum ve Demokrasi, 3 (6-7), 203-216.DOİ.

Köktürk, E. ve Köktürk, E. (2007). Türkiye'de kentsel dönüșüm ve Almanya deneyimi. 11. Türkiye Harita Bilimsel ve Teknik Kurultayı, TMMOB Harita ve Kadastro Mühendisleri Odası, Ankara.

Özden, P. P. (2000). Kentsel yenileme uygulamalarında yerel yönetimlerin rolü üzerine düsünceler ve İstanbul örneği. İstanbul Üniversitesi, Siyasal Bilgiler Fakültesi Dergisi, Prof. Dr. Nazif Kuyucuklu'ya Armağan. 23-24 (255-269).

Tekeli, İ. (2003). Kentleri dönüşüm mekanı olarak düşünmek, kentsel dönüşüm. TMMOB Şehir Plancıları Odası İstanbul Şubesi Yayını, 2-7. ISBN: 975-395-602-9.

TOKİ, (2015). Toplu Konut İdaresi Başkanlığı. Niğde Efendibey Mahallesi 702 adet konut ile altyapı ve peyzaj düzenlemesi işi projeleri.

URL 1, www.haritamap.com/yer/efendibey-mahallesi-merkez (Son Erişim Tarihi: 12.02.2015)

Yaman, M. (2014). Türkiye'de kentsel dönüşüm uygulamaları kapsamında Kütahya kenti Osmangazi kentsel dönüşüm uygulamasına bir bakış. Dumlupınar Üniversitesi Sosyal Bilimler Kütahya Özel Sayısı Kasım: 13-20. 